\title{
Colette Cazenobe, Au malheur des dames. Le roman féminin au XVIII siècle
}

\section{Regina Bochenek-Franczakowa}

\section{(2) OpenEdition}

\section{Journals}

\section{Édition électronique}

URL : http://journals.openedition.org/studifrancesi/8914

DOI : 10.4000/studifrancesi.8914

ISSN : 2427-5856

\section{Éditeur}

Rosenberg \& Sellier

\section{Édition imprimée}

Date de publication : 1 octobre 2008

Pagination : 455

ISSN : 0039-2944

\section{Référence électronique}

Regina Bochenek-Franczakowa, "Colette Cazenobe, Au malheur des dames. Le roman féminin au xvII" siècle », Studi Francesi [En ligne], 155 (LII | II) | 2008, mis en ligne le 30 novembre 2015, consulté le 14 janvier 2021. URL : http://journals.openedition.org/studifrancesi/8914 ; DOI : https://doi.org/10.4000/ studifrancesi.8914

Ce document a été généré automatiquement le 14 janvier 2021.

\section{(c) (i)}

Studi Francesi è distribuita con Licenza Creative Commons Attribuzione - Non commerciale - Non opere derivate 4.0 Internazionale. 


\title{
Colette Cazenobe, Au malheur des dames. Le roman féminin au XVIII ${ }^{\mathrm{e}}$ siècle
}

\author{
Regina Bochenek-Franczakowa
}

\section{RÉFÉRENCE}

COLETTE CAZENOBE, Au malheur des dames. Le roman féminin au XVIII siècle, Paris, Honoré

Champion («Les Dix-huitièmes siècles», 102), 2006, pp. 413.

1 S'il n'y a pas d'écriture féminine proprement dite, affirme C. Cazenobe, le monde fictif nous révèle toujours le sexe de l'écrivain qui l'a produit. À partir de cette constatation, l'A. mène une enquête sur les diverses manières dont les femmes auteurs du XvIII ${ }^{\mathrm{e}}$ siècle ont représenté la condition féminine. L'A. adopte une optique strictement historicolittéraire (l'histoire du roman féminin a ses phases) et biographique (l'œuvre se nourrit du vécu de l'écrivain), ce qui permet d'éviter toute référence aux recherches des gender studies en vogue de nos jours. Ce qui intéresse l'A., c'est «le regard qu'une femme, en tant que femme peut prendre sur sa vie (et la vie en général)» (p. 14). Quatre romancières ont été choisies: Mme Riccoboni, Mme d'Epinay, Mme de Charrière et Mme Cottin dont les romans se trouvent examinés dans le but d'en dégager la représentation de la «destinée féminine» dans ses moments les plus importants. Dans la première partie («Vie des romancières et débuts dans la vie»), après la présentation de la biographie des écrivaines, l'A. se concentre sur les thèmes de la naissance, de l'enfance et de l'éducation dans leurs œuvres. Le reflet des faits de la biographie et des réflexions personnelles des romancières s'y conjugue avec la tradition du roman baroque (les topoi) et l'influence des idées (revendications idéologiques et politiques des philosophes). La deuxième partie («La Femme et l'amour») dessine les divers parcours de la vie sentimentale des héroïnes de romans. Faciles à tromper, sensibles et ingénues, les héroïnes sont les victimes nées de la société de l'époque, semblent suggérer les romans féminins du XVIII ${ }^{e}$ siècle. La troisième partie («Le Mariage et la mort») présente les différentes façons de traiter la «fin de l'histoire»: mariage ou mort. Le mariage étant 
rarement une «fin heureuse», il reste une échappatoire: la mort. Les analyses contenues dans l'ouvrage prouvent que «la vie des femmes est sombre» (p. 329).

2 L'A. soulève la contradiction entre la position, somme toute confortable, des quatre romancières prises en considération dans la société dans laquelle elles ont vécu, et la représentation de la destinée féminine qu'elles donnent, sourde aux joies du présent et aux promesses de l'avenir. L'A. estime à juste titre que la contradiction est celle du siècle des Lumières qui n'a pas trouvé de solution à l'antinomie entre l'universalisme de la pensée philosophique et le particularisme de la tradition. Les romancières se sont donc trouvées prises dans ce «conflit de mentalités» (p. 227). Dans la Conclusion, l'A. se pose la question: en quoi un roman de femme au $\mathrm{xvIII}^{\mathrm{e}}$ siècle peut-il être dit féminin et, éventuellement, féministe? C. Cazenobe penche vers une conclusion modérée, fondée sur «une sorte de vision ou de compréhension commune du destin malheureux des femmes d'élite» (p. 379) qui ressort des romans étudiés. Elle relève aussi ce qui date de l'époque étudiée: le manque de référence à la sexualité et à la maternité. Il n'y a pas de féminisme avant la lettre chez les romancières du XviII ${ }^{e}$ siècle, conclut l'A., mais elle insiste: il faut apprécier leurs «timides velléités» qui seront développées et magnifiées par les femmes écrivains du XIX ${ }^{e}$ siècle, en premier lieu, George Sand. 